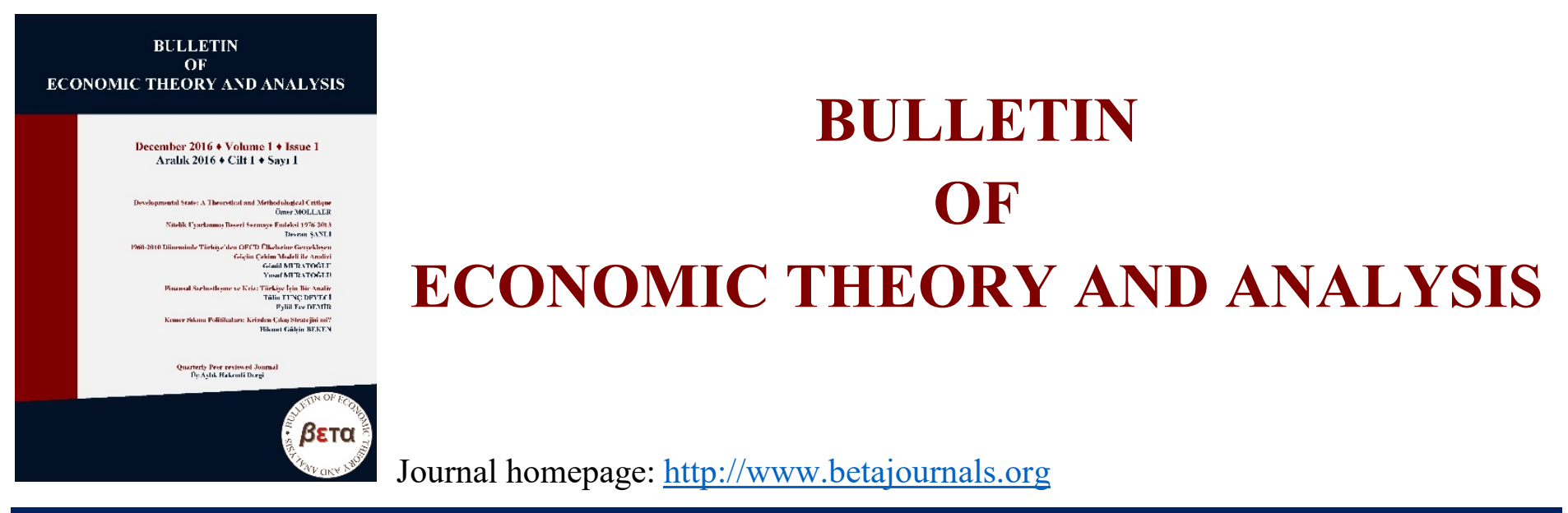

\title{
The Macro-Prudential Measures Taken in Turkey Following the 2008-2009 Global Financial Crisis
}

\section{Z. Tuğrul Göver \& A. Alper Oğuz}

To cite this article: Göver, Z., T. \& Oğuz, A., A. (2017). The Macro-Prudential Measures Taken in Turkey Following the 2008-2009 Global Financial Crisis. Bulletin of Economic Theory and Analysis, 2(1), 1-12.

Received: 17 Jan 2017

Accepted: 26 Feb 2017

Published online: 24 Mar 2017

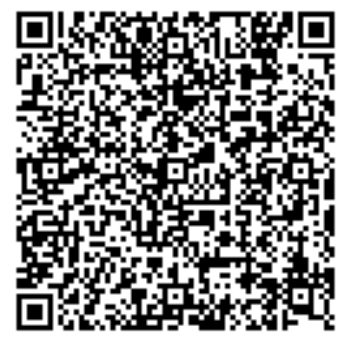




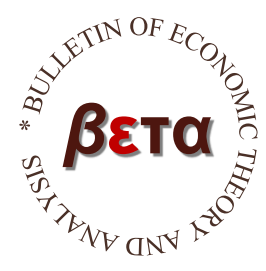

\title{
Bulletin of Economic Theory and Analysis
}

Volume 2, Issue 1, pp. 1-30, 2017

http://www.betajournals.org

\section{The Macro-Prudential Measures Taken in Turkey Following the 2008-2009 Global Financial Crisis}

\author{
Z. Tuğrul Göver ${ }^{\mathrm{a}}$ \\ A. Alper Oğuz ${ }^{b}$ \\ a $\mathrm{PhD}$., Undersecretariat of Treasury/Turkey \\ b World Bank Ankara Office/Turkey
}

\section{ABSTRACT}

The objective of this study is to examine the macro-prudential measures that were taken in Turkey between 2010 and 2015 within a holistic, and, an organized framework, to demonstrate the extent to which the prudential policy tools were used, and, to explain which Basel III standards were adopted in Turkey. In this sense, to our knowledge, this is the first and the most comprehensive study that deals with the macro-prudential measures in Turkey during the period 2010-2015. We reviewed all relevant legislation and reports regarding financial stability and macro-prudential measures. Then, we fit all macro-prudential policy tools into a framework which consists of loan-related measures, liquidity-related measures, and, capital-related measures. Furthermore, we incorporated Basel III standards with our framework in order to expand the scope of our analysis. Within the period under consideration, Turkey utilized all of the tools, except the limit on foreign currency lending, the limit on net open foreign currency position, the limit on currency mismatches. The authorities put 93 regulations into practice in total. 2013, 2011 and 2015 were the years in which the regulations were issued most extensively.
\end{abstract}

\section{Keywords}

Global Financial Crisis, Financial Stability, MacroPrudential Policy, Basel III

JEL Classification G01, G18, G28

CONTACT Z. Tuğrul GÖVER, Corresponding author. $₫$ govertugrul@yahoo.com $\Xi^{\prime}$ Undersecretariat of Treasury/Turkey. 


\title{
2008-2009 Küresel Finansal Krizi Sonrasında Türkiye'de Alınan Makro İhtiyati Tedbirler
}

\section{ÖZ}

Bu çalışmanın amacı, Türkiye'de 2010-2015 yılları arasında alınan makro-ihtiyati tedbirleri bütüncül ve sistematik bir çerçevede incelemek, ihtiyati politika araçlarının ne ölçüde kullanıldığını göstermek ve Türkiye'de uygulamaya koyulan Basel III standartlarını açıklamaktır. Bu anlamda, bildiğimiz kadarıyla, bu çalışma 2010-2015 döneminde Türkiye'de alınan makro ihtiyati tedbirlerin tamamını ele alan ilk ve en kapsamlı çalışmadır. Bu çalışma yapılırken finansal istikrara ve makro-ihtiyati tedbirlere ilişkin tüm ilgili mevzuat ve raporlar incelenmiş ve kullanılan makro-ihtiyati politika araçları, krediyle ilgili, likiditeyle ilgili ve sermaye ile ilgili tedbirlerden oluşan bir çerçeve içerisinde değerlendirilmiştir. Ayrıca, çalışmanın analiz kapsamını genişletmek için literatürdeki mevcut çerçeveye Basel III standartları da dahil edilmiştir. Çalışma kapsamındaki dönemde, Türkiye'de döviz cinsi kredileri kısıtlama, net açık döviz pozisyonunu kısıtlama ve para birimi uyumsuzluklarını kısıtlama hariç olmak üzere tüm araçlar kullanılmıştır. 2010-2015 yılları arasında politika yapıcı kurumlar tarafından toplam 93 düzenleme uygulamaya konmuştur. Makro-ihtiyati tedbirlerin en yoğun şekilde kullanıldığı yıllar sirasıyla 2013, 2011 ve 2015’tir.

\author{
Anahtar Kelimeler \\ Küresel Finansal \\ Kriz, Finansal \\ İstikrar, Makro \\ İhtiyati Politikalar, \\ Basel III \\ JEL Kodu \\ G01, G18, G28
}

\section{Introduction}

With the 2008-2009 Global Financial Crisis, it is acknowledged that focusing solely on the price stability is not enough to contain the build-up of economic crises (Blanchard, Dell'Ariccia \& Mauro, 2010). In the period following the 2008-2009 crisis, macro-prudential policies have come to the forefront, as well as, systemic risk and financial stability concepts. Systemic risk, which is a broad concept, roughly expresses the risks that may arise from the contagion of shocks within the financial system (Galati \& Moessner, 2011; Hellwig, 2014). According to Caruana (2010) macroprudential policies are defined as precautionary measures aimed at supporting the stability of the financial system as a whole. The objective of macro-prudential policies is expressed as to reduce systemic risk that emanates from the credit cycles, and, the institutions, in other words the crosssectional dimension, of the financial system.

So far, various classifications on the tools that can be used for the implementation of macro-prudential policies have been proposed. In a study (2011) published by the Bank of England (BOE), macro-prudential measures were examined in three groups. Namely, the measures that affect conditions related to balance sheet, the structure of the market, and, lending. On the 
other hand, Lim et al. (2011) classified macro-prudential tools in three groups with a different approach. Their broad groups include, credit-related measures, liquidity-related measures, and, capital-related measures. In addition to the available policy tools, Basel Committee on Banking Supervision (BCBS) set new standards for the banking sector with the Basel III consensus. These standards are also considered macro-prudential measures. Basel III consensus established the rules for the liquidity coverage ratio, the net stable funding rate, the leverage ratio, the capital conservation buffer, and the countercyclical capital buffer; defined common equity capital and Tier 1 capital, and, set limits to these capital definitions (BIS, 2011). In this study we adopted, primarily, Lim et al.'s (2011) classification as a guide. In addition, we incorporated the new rules introduced by the BCBS with Lim et al.'s framework.

Like many other developing countries the need to take action against the potential risks in the financial system emerged in Turkey following the Global Financial Crisis. From 2010 onwards, the policy-making institutions, especially, the Central Bank of the Republic of Turkey and the Banking Regulation and Supervision Agency made many regulations. In addition, Turkey adopted Basel III standards to a large extent. In the period following the 2008-2009 Global Financial Crisis the key drivers, that pushed Turkey to implement the macro-prudential policies, were the rapid economic recovery and the excessive rate of credit growth, which surpassed $30 \%$ in 2011.

The objective of this study is to examine the macro-prudential measures that were taken in Turkey between 2010 and 2015 within a holistic, and, an organized framework, to demonstrate the extent to which the macro-prudential policy tools were used, and, to explain which Basel III standards were adopted in Turkey. In this sense, to our knowledge, this is the first and the most comprehensive study that deals with the macro-prudential measures in Turkey during this period. The study consists of three chapters. The first chapter presents a brief discussion on the significance of macro-prudential policies for financial stability, and, then explains under what conditions Turkey resorted to the prudential instruments. In the second chapter we elaborate the macro-prudential measures taken in Turkey between 2010 and 2015. The third chapter is dedicated to the assessment of the macro-prudential measures. 


\section{The Emergence of Macro-prudential Policies and the Impact of the Global Financial Crisis in Turkey \\ 2.1. Financial Stability and the Call for Macro-prudential Policies}

The 2008-2009 Global Financial Crisis severely hit the global economy, and, particularly the financial institutions. In the aftermath of the crisis, international organizations and scholars had to admit that maintaining price stability and sticking with the prudential rules valid before 2008 could not restrain the build-up of systemic risk in the global financial system (Blanchard, Dell'Ariccia \& Mauro, 2010). In order to strengthen the financial system numerous reform recommendations were put forward. For example Hannoun (2010) stressed the significance of monetary and fiscal policies for financial stability, and, came up with a holistic perspective. His vision of the new financial stability framework regarded prudential, monetary and fiscal policies as integral components of a sound system. He suggested that, monetary policy should not only focus on price stability, but also take countercyclical action to tackle financial imbalances within the new paradigm. Since our objective is to analyze the macro-prudential policies in this study, we narrow down our focus on the instruments related to prudential policies. Caruana (2010) suggested that the aim of the macro-prudential policies was supporting the stability of the financial system as a whole. In a detailed survey on the origins of the term "macro-prudential" Clement (2010) emphasized that a macro-prudential approach should cover two dimensions, namely the time dimension and the cross-sectional dimension. The time dimension refers to the change in the aggregate risk over financial cycles. Financial institutions usually have a tendency to be overoptimistic in the boom periods, and, implicit risks in the financial system may suddenly go up to the surface during the busts. In this regard, macro-prudential policies should seek ways to address the procyclicality problem. The cross-sectional dimension is about the distribution of the aggregate risk, which may be uneven, across the individual financial institutions at a given time period. Loose supervision mechanisms may provide incentive to some banks to accumulate excessive risks. Thus, macro-prudential policies should also oversee the behavior of the individual financial companies (Hannoun, 2010). From this point of view many countries, especially developing countries, resorted to macro-prudential measures as a complementary policy package to monetary and fiscal policies following the 2008-2009 Global Financial Crisis. Along the lines with these developments, Turkey started using a number of macro-prudential instruments from 2010 onwards. In the next section we explain the damage that the crisis made on Turkey's 
economy and why the decision-making authorities wanted to make use of the macro-prudential tools.

\subsection{The Impact of the 2008-2009 Global Financial Crisis on Turkey}

The impact of the Global Financial Crisis that broke out in 2008 on Turkey's economy was striking. Turkey began to witness the adverse effects of the global crisis in 2008, and the GDP growth was dwarfed to 0.8 percent. This was followed by a contraction in GDP of 4.7 percent in 2009, and, a rise in unemployment rate which exceeded 16 percent within 2009. One of the main channels that the global crisis affected Turkey's economy was capital flows. The high GDP growth between 2002 and 2007, supported by abundant capital inflows and global liquidity, led to an increase in the indebtedness of the private sector. However, the dry-out in capital flows during the global crisis drove the private banks to stop granting new loans, and, recall existing loans. Consequently the bank loans were severely curtailed during the crisis. Moreover, as regards the capital markets, The Istanbul Stock Exchange (BIST) lost more than half of its value in 2008 (Table 1).

Table 1

Key Macroeconomic Indicators of Turkey, 2006-2011

\begin{tabular}{lrrrrrr}
\hline & $\mathbf{2 0 0 6}$ & $\mathbf{2 0 0 7}$ & $\mathbf{2 0 0 8}$ & $\mathbf{2 0 0 9}$ & $\mathbf{2 0 1 0}$ & $\mathbf{2 0 1 1}$ \\
\hline Real output growth, percent & 7.1 & 5.0 & 0.8 & -4.7 & 8.5 & 11.1 \\
Unemployment, percent & 8.9 & 9.2 & 12.0 & 11.9 & 10.0 & 8.5 \\
Real credit growth, percent & 34.9 & 26.8 & 12.0 & 4.1 & 24.9 & 17.4 \\
Capital flows / GDP, percent & 7.8 & 7.3 & 4.5 & 1.5 & 7.7 & 8.0 \\
Market capitalization of BIST 100, USD Billion & 162.5 & 288.3 & 119.1 & 231.7 & 295.8 & 191.1 \\
Current account / GDP, percent & -5.7 & -5.4 & -5.1 & -1.7 & -5.8 & -8.9 \\
Fixed investments / GDP, percent & 28.7 & 28.1 & 26.8 & 22.4 & 24.9 & 28.1 \\
Industrial production index (average) & 92.7 & 100.6 & 99.5 & 89.1 & 100.2 & 109.9 \\
\hline
\end{tabular}

Note. End-year figures unless stated otherwise. Source: CBRT, TURKSTAT

In the years following the global crisis the liquidity provided to the financial system, through unconventional monetary policies, to support economic growth in developed economies, moved towards more attractive developing countries, including Turkey. The acceleration of capital flows in a short time period, led to the appreciation of Turkish Lira, and, rapid credit growth in Turkey. Those developments, in turn, triggered aggregate consumption and imports, and as a consequence, the current account deficit rose up to 8.9 percent of GDP in 2011. Under these 
circumstances the authorities in Turkey recognized that the economic policies should also support the financial stability.

The Central Bank of the Republic of Turkey (CBRT) introduced the exit strategy and a new policy mix, which took the financial stability into account as well, in 2010. In order to control for the financial stability the CBRT set two key indicators, namely, the short-term capital inflows, and, the domestic credit growth (Başçı \& Kara, 2011). Indeed, a study on the diagnosis of the credit growth in Turkey showed that the credit volume grew excessively in 2010 and 2011. The authors concluded that the excessive credit growth could pose a threat to the financial stability in Turkey (Binici \& Köksal, 2012). Thus the CBRT was right in picking the domestic credit growth as a key indicator along with the short-term capital flows. The CBRT started to use monetary policy instruments such as the interest rate corridor, and, macro-prudential policy tools like reserve requirements simultaneously for maintaining the financial stability in late 2010. As the authority to regulate the money market, the foreign exchange market, and the credit market was granted to a number of decision-making institutions in Turkey, the CBRT's endeavors had to be supported by the institutions like the Banking Regulation and Supervision Agency (BRSA). Since we focus solely on the macro-prudential measures, we will not delve into the monetary policy instruments. The remainder of this study is dedicated to elaborate the macro-prudential measures taken by the authorities in Turkey.

\section{Macro-prudential Policy Instruments Used in Turkey in 2010-2015}

\subsection{Credit-related Macro-prudential Measures}

Measures to affect credit volume and/or credit expansion directly or indirectly are classified in this group. According to Lim et al. (2011) credit-related measures consist of four policy tools: 1- limiting credit expansion, 2- changing Loan-to-Value ratio, 3- changing Debt-toIncome ratio, 4- limiting foreign currency lending. Our review revealed that three out of the four tools listed above were used in Turkey between 2010 and 2015. However, Turkey did not make any significant regulation on foreign currency lending.

\subsubsection{Limiting credit expansion}

Credit expansion in Turkey has been considered a systemic risk factor by the economic administration in the period following the Global Financial Crisis. The BRSA, the CBRT and the Savings and Deposits Insurance Fund (SDIF) took a number of measures in order to contain the 
credit expansion during the period 2010-2015. Most of these measures were put into force by the BRSA.

The BRSA increased the minimum payment requirements set for the credit cards in 2010 . It envisaged a gradual increase in minimum payment rates as a percentage of the spending limits until 2014. The purpose of the regulation was to force the consumers to change their perception about the credit cards, and, discourage the use of the cards as a means of individual finance. At the beginning of 2014, the BRSA made a similar adjustment, and, once again raised the minimum payment requirements. The table below displays the changes in the payment requirements of credit cards (CBRT, 2014b).

Table 2

Minimum Payment Requirements Set for Credit Cards

\begin{tabular}{lccc}
\hline $\begin{array}{l}\text { The spending limit through } \\
\text { credit card }\end{array}$ & $\begin{array}{c}\text { Minimum payment } \\
\text { requirements, as of } \\
\mathbf{2 0 1 0}\end{array}$ & $\begin{array}{c}\text { Minimum payment } \\
\text { requirements, as of 2014 }\end{array}$ & $\begin{array}{c}\text { Minimum payment } \\
\text { requirements, as of } \\
\mathbf{2 0 1 5}\end{array}$ \\
\hline$<$ TRL 15,000 & $20 \%$ & $25 \%$ & $30 \%$ \\
TRL 15,000-20,000 & $20 \%$ & $30 \%$ & $35 \%$ \\
> TRL 20,000 & $20 \%$ & $40 \%$ & $40 \%$ \\
\hline
\end{tabular}

Source: BRSA

The BRSA put two more measures into force to cool the credit growth in early 2014 . The first regulation limited the maturity of all consumer loans, other than housing loans, to 36 months and vehicle loans to 48 months. Another important measure was setting the maximum number of monthly installments to nine as a general rule for the purchases made through credit cards. The BRSA removed the advantage of paying the credit card expenditures in monthly installments in certain sectors such as telecommunication and jewelry. On the other hand, in 2015Q4, the BRSA relaxed some of the restrictions on credit expansion (CBRT, 2014b; BRSA, 2015; BRSA, 2016).

To help contain the credit growth, the SDIF changed the insurance premiums applied to the credit institutions in 2011, and, made the credit institutions with larger asset sizes to pay an additional premium. In 2013, in order to control the volume of the loans provided by the financing companies, the CBRT expanded the coverage of the reserve requirement system by including the Turkish Lira (TRL) and foreign currency liabilities of these companies (CBRT, 2011b; CBRT, 2013b). 


\subsubsection{Changing loan-to-value ratio}

Loan-to-Value (LTV) ratio is a countercyclical tool for managing the developments in the credit volume in an economy. Turkey employed this tool during the period 2010-2015. The BRSA holds the power to determine the LTV ratio in Turkey.

In December 2010, the BRSA restricted the LTV ratio for housing loans. According to the regulation, from 2011 onwards, the maximum amount of housing loans was limited to $75 \%$ of the value of the property which was subject to collateral. The BRSA also put a 50\% cap on the LTV ratio, for the corporate loans provided to purchase commercial real estate (CBRT, 2011a).

The rapid growth of the vehicle loans urged the BRSA to re-determine the LTV ratio on vehicle loans in 2014. The LTV ratio was set at a maximum of $70 \%$ for the vehicles that valued TRL 50,000 or less. For the vehicles that valued more than TRL 50,000, the LTV ratio was set to $70 \%$ for the portion up to TRL 50,000, and, 50\% for the exceeding part (CBRT, 2014b).

\subsubsection{Changing debt-to-income ratio}

Debt-to-Income (DTI) ratio is, primarily, an instrument to restrain the households' tendency for excessive borrowing that is incompatible with their income. In 2013 two regulations similar to limiting the DTI ratio were put into force by the BRSA in Turkey.

The first arrangement made the credit institutions set a single, and, unified spending limit, which was compatible with the person's income level, for the real persons who would have a credit card for the first time. In case more than one bank granted credit cards to a real person, the sum of the limits of those credit cards would not exceed the total spending limit allocated for that person. The total spending limit for the credit cards set by the credit institutions would not exceed twice the cardholder's average monthly net income within the first year, and, four times the average income within the second year following the limit-setting date. The second regulation was complementary to the first one, and, it set the rules regarding the increases in credit card limits. The regulation forbade the card issuing institutions to raise the limit of a credit card without receiving the cardholder's formal confirmation. Furthermore, the BRSA prohibited the credit institutions to raise the limit when the total credit card limit provided by the card issuers reached four times the cardholder's average income (CBRT, 2013b). 
Credit-related macro-prudential measures in Turkey were mostly confined to the loans granted to the individuals in the form of credit cards, and, consumer loans, during the period 20102015. However, the authorities did not make any major arrangements to moderate corporate loans. We suggest that the rate of increase in personal loans was the key driver in opting for this policy.

\subsection{Liquidity-related Macro-prudential Measures}

The measures to affect the liquidity in the financial system are classified under this group. According to Lim et al. (2011) four policy tools can be considered liquidity-related: 1- limiting net open foreign exchange position, 2- limiting currency mismatches, 3- limiting maturity mismatches, 4- changing reserve requirements. Two out of the four policy tools listed above were used in Turkey between 2010 and 2015. However, no regulation was made in order to limit net open foreign currency position and currency mismatches in the financial sector. In addition to the tools suggested by Lim et. al.'s study, Basel III consensus launched the Liquidity Coverage Ratio and the Net Stable Funding Rate for managing the liquidity in the financial system.

\subsubsection{Limiting maturity mismatches}

Maturity mismatch refers to a low liquidity level in a financial organization, and, it usually arises from the inconsistency between short-term liabilities and long-term assets. In such a case, banks may face difficulties in finding the liquidity they need in order to conduct their financial operations. For this reason, the authorities, mostly, resort to the measures leading to the extension of the maturities of the liabilities such as deposits to expand the liquidity in the system. During the period 2010-2015, the authorities made 18 regulations to alleviate the maturity mismatches in Turkey. Of those, 15 were concerning the differentiation of the reserve requirements by the maturities of the time deposits, and, put into force by the CBRT.

In 2011, the CBRT differentiated the reserve requirements by maturity for the local currency (TRL) deposits first, and, then for the deposits in foreign currencies. In this way, the CBRT aimed to increase the cost of banks' short term liabilities. The CBRT made arrangements to raise the reserve requirement ratios of the banks for short-term time deposits, i.e. maturities less than six months, in Turkish Lira. Consequently, reserve requirements for short-term deposits rose rapidly throughout 2011 while the reserve requirement ratios for longer term time deposits in TRL kept fixed. Moreover, in February 2011, the CBRT declared that all non-deposit liabilities in TRL would be subject to reserve requirement, and, the ratio set for the three-month time deposits would 
be applied to those liabilities. Similar arrangements came into effect for the foreign currency time deposits in the second half of 2011. In addition to these measures, in order to extend the maturity of non-deposit liabilities of the banks, the CBRT issued more regulations regarding the reserve requirements in 2015. The CBRT raised the reserve requirements for the loans, borrowed by the domestic banks from various financial institutions, with a maturity less than three years rapidly from 2015 onwards (CBRT, 2011a; CBRT 2015).

In 2011, the SDIF made two amendments to the communique concerning the insurance premiums of the banks for the deposits they collect. With the first amendment the SDIF decided to take the average maturity of deposits into account for the calculation of the insurance premiums on deposits. The second regulation required the banks, which held shorter average maturity deposits, to pay higher insurance premiums to the SDIF (CBRT, 2011b).

Turkey continued its endeavors to moderate the maturity mismatches in 2013. The Council of Ministers released two resolutions with the aim of promoting the long-term deposits in 2013. One of them was a tax regulation on time deposit accounts. The withholding tax, applied at a $15 \%$ flat rate on the yield of time deposits regardless of the maturity, was differentiated according to the maturities of time deposits in both TRL and foreign currencies. The resolution decreased the rates applied to longer term time deposits. The table below summarizes the changes in the withholding tax rates on time deposits (Table 3). The second resolution allowed the depositors to withdraw up to $50 \%$ fragment of their total deposit, with a maturity over one year before the end of the maturity, without losing any interest revenue (CBRT, 2013a).

Table 3

Withholding Tax Rates Imposed on Time Deposits in Turkey

\begin{tabular}{|c|c|c|c|c|}
\hline \multirow[b]{2}{*}{ Maturity } & \multicolumn{2}{|c|}{ Withholding tax on deposits in TRL } & \multicolumn{2}{|c|}{$\begin{array}{l}\text { Withholding tax on deposits in foreign } \\
\text { currencies }\end{array}$} \\
\hline & Before 2013 & After 2013 & Before 2013 & After 2013 \\
\hline $\begin{array}{l}\text { Demand deposits and time } \\
\text { deposits with a maturity }\end{array}$ & & $18 \%$ & & $15 \%$ \\
\hline $\begin{array}{l}<6 \text { months } \\
6 \text { months }-1 \text { year }\end{array}$ & $15 \%$ & $15 \%$ & $15 \%$ & $12 \%$ \\
\hline$>1$ year & & $13 \%$ & & $10 \%$ \\
\hline
\end{tabular}

Source: CBRT 


\subsubsection{Changing reserve requirements}

Central Banks employ reserve requirements as one of the traditional instruments of monetary policy for regulating the money market. Central Banks can affect both liquidity and credit volume through changing reserve requirements. In Turkey, during the Global Financial Crisis, in order to increase the liquidity facilities in the financial markets the CBRT cut the reserve requirement ratios on the deposits in foreign currencies in 2008, and, on Turkish Lira deposits in 2009. The Monetary and Foreign Exchange Policy Report 2010 and the Exit Strategy declared by the CBRT in 2010 stated that the reserve requirements would be used as a complementary tool to the main policy instrument, which was the interest rate. Thus, the CBRT used the reserve requirements more actively within the framework of the new strategy implemented since 2010 (CBRT, 2009; CBRT, 2010).

The CBRT adjusted the reserve requirement ratios on TRL and foreign currency liabilities during the period 2010-2015 along the lines with its exit strategy. Given that the changes in the reserve requirement ratios affected the liquidity level in the market, the CBRT aimed at using the reserve requirements as a multi-purpose tool as well. For example, as explained in the previous section, the CBRT endeavored to tackle maturity mismatches between the assets and liabilities of the banks through differentiating the reserve requirement ratios by the maturities of deposits.

On the other hand, the CBRT transformed the reserve requirements into the Reserve Option Mechanism (ROM) in 2011 to support the financial stability in Turkey after the Global Financial Crisis. Therefore, the arrangements regarding the reserve requirements after 2011Q3 will be addressed in the following section which is dedicated to the ROM. In addition, the CBRT introduced another novel tool called the leverage based reserve requirement in 2014 to support financial stability.

\subsubsection{Non-traditional macro-prudential instruments related to reserve requirements}

\subsection{Reserve option mechanism}

In 2011, the CBRT transformed the reserve requirements into an instrument called the Reserve Option Mechanism (ROM), which can also be called as a financial innovation. This instrument basically allows the financial institutions to keep a certain part of the reserve requirements set for the TRL and foreign currency liabilities in US Dollars and/or standard gold at the CBRT, instead of TRL. The ROM is primarily designed to mitigate the potential pro-cyclical 
effects of the capital flows on exchange rates and credit growth. The idea is that a part of the capital inflows will be added directly to the official reserves of the CBRT through the ROM without getting in circulation in the financial markets if the banks opt for this instrument when the net capital inflows into Turkey are booming (Alper, Kara \& Yörükoğlu, 2012).

The determinants of the Reserve Option Mechanism are the Reserve Option Ratio (ROR) and the Reserve Option Coefficient (ROC). In case the banks prefer to use the ROM, they should know the ROR and the ROC in order to calculate how much foreign exchange or gold to deposit at the CBRT as reserve requirement instead of TRL. The ROR specifies how much of the reserve requirements in TRL can be set in USD or gold. For example, if the ROR is set at $10 \%$, that means a bank can set up to $10 \%$ of its reserve requirements at the CBRT in USD or gold. The ROC means how many units of USD or gold can be deposited for each Turkish Lira. We reckon an illustrative example might be helpful for understanding how the ROM works. We suppose the reserve requirement sum for a bank in Turkish Lira is 100, and, the CBRT sets the ROR at 10\% and the ROC at 2. Under these conditions, if a bank wants to take advantage of the ROM, it can substitute either USD or gold equivalent of TRL 20, and, deposit the remaining TRL 80 in the local currency. The design of the ROM suggests that the liquidity in TRL will rise as the banks prefer to use the ROM more (Alper, Kara \& Yörükoğlu, 2012; Özatay, 2013).

As the ROM is planned to be a market-friendly tool, using this mechanism is not mandatory, and, the choice is left to the financial institutions. Under the ROM, banks compare the cost of borrowing in TRL and in foreign currency when establishing the reserve requirements. It is expected that the banks will benefit from the ROM when the cost of borrowing in TRL is higher than the cost of the funds in foreign currency. In general, the periods in which net capital inflows accelerate coincide with the periods in which global liquidity is abundant. The banks may prefer to use the ROM because the cost of foreign currency funds will be relatively low under the circumstances. Consequently, following a surge in net capital inflows, the likelihood of overvaluation in Turkish Lira, and, recycling the surplus foreign exchange in banks by lending will decrease. Because the major part of the excess foreign currency will be pulled from the financial markets if the banks prefer to resort to the ROM. On the other hand, the mechanism will work in the opposite direction in case of a contraction in net capital inflows, and, the banks will benefit less from the ROM and withdraw the foreign currency they hold at the CBRT. This will lead to an increase in the amount of foreign exchange in the market and TRL will depreciate more 
smoothly according to the working principle of the ROM. Thus the ROM will function as an automatic stabilizer during both capital inflow and outflow sequences (Alper, Kara \& Yörükoğlu, 2012; Vural, 2013).

The CBRT introduced the ROM gradually from 2011Q3 onwards. Thus, the CBRT allowed for sufficient time to the banks to adapt themselves to this new instrument. At the outset the CBRT allowed the banks to establish up to $10 \%$ of the reserve requirements in US Dollars or in standard gold, in other words, the ROR was set to $10 \%$. Later on, the RORs were gradually increased to $60 \%$ for the ROM in USD and to $30 \%$ in gold. Furthermore, the RORs were differentiated by percentiles, and, the ROCs associated with the ROR tranches were differentiated as well. The RORs and the ROCs to be applied to the reserve requirements in US Dollars and in gold are given in the table below as of end 2015 (CBRT, 2011b; Alper, Kara \& Yörükoğlu, 2012; CBRT, 2016).

Table 4

The ROM as of end-2015

\begin{tabular}{ccccc}
\hline $\begin{array}{c}\text { Number of } \\
\text { tranches }\end{array}$ & $\begin{array}{c}\text { ROM tranches in } \\
\text { USD (\%) }\end{array}$ & ROCs on USD ROM & $\begin{array}{c}\text { ROM tranches in gold } \\
\mathbf{( \% )}\end{array}$ & $\begin{array}{c}\text { ROCs on gold } \\
\text { ROM }\end{array}$ \\
\hline 1 & $0-30$ & 1,0 & $0-15$ & 1,4 \\
2 & $30-35$ & 1,5 & $15-20$ & 1,5 \\
3 & $35-40$ & 1,9 & $20-25$ & 2,0 \\
4 & $40-45$ & 2,3 & $25-30$ & \\
5 & $45-50$ & 2,7 & & \\
6 & $50-55$ & 3,1 & & \\
7 & $55-56$ & 3,9 & & \\
8 & $56-57$ & 4,1 & & \\
9 & $57-58$ & 4,3 & & \\
10 & $58-59$ & 4,5 & & \\
11 & $59-60$ & 4,7 & & \\
\hline
\end{tabular}

Source: CBRT

\subsection{Leverage based reserve requirements}

The leverage ratio under Basel III consensus, which was introduced by the Basel Committee on Banking Supervision (BCBS), will be tested by the member states at 3\% level from 2013 and will be binding for the BIS members in 2018 (BIS, 2011).

The leverage ratio of the banking sector in Turkey had been moving around 8\% since 2005 and it was at $7.5 \%$ as of $2015 \mathrm{Q} 4$. Needless to say these figures were much higher than the 3\% tested ratio. Hence, it was obvious that the banking sector in Turkey was not exposed to a risk due 
to the level of leverage ratio. However, the CBRT kept its cautious stance on borrowing activities of the banks operating in Turkey, and, launched the leverage based reserve requirement (LBRR), which was another novel tool, in 2014. The CBRT declared that, based on 2013Q4 data, it would impose an additional $2 \%$ reserve requirement for the banks with a leverage ratio of $3 \%$ or less, and, $1.5 \%$ reserve requirement for the banks with a leverage ratio in $3-3.5 \%$ range, in 2014 . The leverage ratios that would be subject to the LBRR were gradually increased up to $5 \%$ at the end of 2015 (CBRT, 2013a; Vural, 2013).

\subsubsection{Liquidity coverage ratio}

The 2008-2009 Global Financial Crisis proved that the capital adequacy ratio rule applied to the banking system cannot guarantee any immunity to a financial crisis. This criterion itself cannot protect the banks from facing liquidity problems. For this reason, the BCBS introduced two new global liquidity standards along with Basel III settlement. The first one is the Liquidity Coverage Ratio (LCR). The aim of launching the LCR is to strengthen the short-term liquidity risk profile of the banks by urging them to use their high quality liquid assets against the volatile movements in the markets over a thirty-day period (BIS, 2011). The high quality liquid assets include the assets that constitute reliable sources of liquidity that can be measured easily and accurately such as the receivables from the Central Bank, the securities under government guarantee and the government bonds.

The LCR is calculated by dividing the high-quality liquid asset stock of a bank by the difference between the bank's cash outflows and inflows, in other words net cash outflows, within thirty days, and, the ratio should be maintained at least at $100 \%$. However, the BIS allowed the member countries to adapt gradually to this rule until end-2018. It is envisaged that the LCR would be binding from 2019 on. In 2014, the BRSA issued the communique regarding the adaptation procedures on the LCR. According to the new regulation the overall LCR should be maintained at least at $60 \%$ and the foreign currency LCR should be maintained at least at $40 \%$. The communique set forth ten percentage points increase in those LCRs every year starting from 2016 till they hit 100\% and 80\%, respectively, in 2019 (BRSA, 2015). 


\subsubsection{Net stable funding rate}

The second global liquidity standard introduced by Basel III consensus is the Net Stable Funding Rate (NSFR). This standard aims at strengthening the liquidity position of the banks, and, enabling them to obtain the liquidity, that the banks need, from more reliable resources. Thus, the NSFR requires the banks to fund their long term assets with long term liabilities (BIS, 2014).

The NSFR is calculated by dividing the available stable funding amount (ASF) to the required stable funding amount (RSF). The BCBS settled that this ratio should be maintained at least at $100 \%$. In order to obtain the ASF, the liabilities of the banks are classified in five groups according to the maturity and the liquidity characteristics, and, multiplied by the weights assigned to each group $(\% 100, \% 95, \% 90, \% 50, \% 0)$. On the other hand, to calculate the RSF the assets of the banks are classified in eight groups according to the maturity and the liquidity characteristics, and, then multiplied by the given weights $(0 \%, 5 \%, 10 \%, 15 \%, 50 \%, 65 \%, 85 \%, 100 \%)$. The purpose of following this method is to determine the assets that would need funding within the year ahead. In obtaining the ASF and the RSF, longer-term assets and liabilities are multiplied by higher weights. The NSFR will be implemented as a minimum standard for the banking sector in 2018 (BIS, 2014). Turkey has not issued any regulation regarding the adoption of the NSFR rule yet.

\subsection{Capital-related Macro-prudential Measures}

The measures to ensure that financial institutions have a strong capital structure are classified under this group. In addition to traditional instruments such as capital adequacy ratios for regulating the capital structure of the finance companies, a couple of novel instruments launched by the BCBS such as the leverage ratio, and, the capital conservation buffers are included in this group as well.

\subsubsection{Countercyclical capital requirements}

The minimum capital adequacy ratio, which is designed in order to maintain the stability of the financial system, requires the banks to have sufficient equity for counterweighing the assets exposed to risk. Changing the minimum capital adequacy ratio or the risk weights of the loans in certain types according to the credit cycles is used as a countercyclical prudential tool. Thus, provided that the banks maintain the minimum ratio, the authorities expect that the banking sector would be less affected by the fluctuations in the financial system. The BRSA and the CBRT made 
a number of regulations to strengthen the capital structure of the banking system in Turkey during 2011-2015.

Since the average minimum capital adequacy ratio in Turkey had been above the lower limit of $8 \%$, which was set by the BCBS, the BRSA regulated the equity level of the banks by adjusting the risk weights. The BRSA re-classified the consumer loans by maturity through an arrangement in 2011, and, the risk weight for the loans with 12-24 months maturity was raised to $150 \%$, and, for those with maturity longer than 24 months the risk weight was increased to $200 \%$. In October 2013, the BRSA reset the risk weights of purchases in installments through credit cards, and, vehicle loans. According to the new regulation, the risk weight of the sum of the future payments to be made in installments with a maturity of 1-6 months was raised from $75 \%$ to $100 \%$. Concerning the other groups, the risk weights were raised from $150 \%$ to $200 \%$, and, from $200 \%$ to $250 \%$, for the purchases with a maturity of 6-12 months and a maturity longer than 12 months, respectively. The risk weight of the receivables on the vehicle loans, with a maturity of 12-24 months, was increased from $75 \%$ to $100 \%$. On the other hand the risk weight assigned to the vehicle loans with a maturity longer than 24 months was increased from $75 \%$ to $200 \%$ (BRSA, 2012; BRSA, 2014).

The BRSA introduced the definitions of the common equity capital adequacy ratio and the Tier 1 capital adequacy ratio in line with Basel III consensus, and, set the minimum ratios related to these capital definitions in 2014. It is important to note that, the common equity capital has the highest loss absorbency capacity among various capital definitions. The BRSA settled that maintaining the common equity capital adequacy ratio at least at $4.5 \%$, and, the Tier 1 capital adequacy ratio at least at $6 \%$ would be obligatory for the banks operating in Turkey. Yet, the minimum capital adequacy ratio of 8\% was kept intact (BIS, 2011; CBRT, 2014a; BRSA, 2014).

The CBRT began to use the interest paid on the reserve requirements as an incentive to encourage the financial institutions to bolster their core liabilities (deposit + equity) in 2015. Accordingly, the CBRT committed to pay more interest to those institutions whose core liabilities stood above the average of the banking sector (CBRT, 2014b). 


\subsubsection{Changing loan-loss provisions}

Loan-loss provision is the provision that the banks are required to allocate for the potential losses that can emanate from insolvency of the debtors, or, restructuring in the loan portfolios of the banks. The loan-loss provision rates indirectly affect the lending capacity of the banks. For this reason, the regulatory agencies responsible for the stability of the financial sector can use such provision rates to regulate the credit cycles. The BRSA is empowered to change the provision rates in Turkey. The banking authority used the general provision rates in 2011, 2013 and 2015 as an instrument.

The BRSA took action to suppress the consumer loans through an arrangement regarding the general provisions in 2011. The provision rates were quadrupled for the banks that provided relatively more consumer loans, except housing and vehicle loans. Thus, the general provision rates were set at 4\% for the loans in Group I, which stands for standard loans and other receivables, and, at $8 \%$ for the ones in Group II, meaning closely monitored loans and other receivables (CBRT, 2014b).

In 2013, the BRSA expanded the coverage of the regulation made in 2011, and, the vehicle loans became subject to general provision. The arrangement envisaged a gradual implementation of the provisions until the end of 2015. The BRSA settled that the general provision ratios on the vehicle loans would be applied at 4\% throughout the entire maturity for the loans classified in Group I, and, at 8\% for the loans monitored in Group II eventually. In addition, a communique issued in 2013 made the financing companies liable for allocating general provisions for the loans they grant. Accordingly, financing companies obliged to allocate general provisions at $4 \%$ for the standard consumer loans, except the housing loans, and, at 8\% of the consumer loans 30-90 days overdue. The BRSA made another amendment to the communique on the consumer loans in 2013. With the arrangement, the loans granted to real persons through credit cards in cash or for purchase of good and services, and, overdraft accounts dependent on saving accounts belonging to real persons were included in the official definition of consumer loans. As a consequence, the scope of the restrictions imposed on consumer loans were expanded (CBRT, 2014a; CBRT, 2014b).

In 2015, the BRSA lowered the general provisions that the financing companies should allocate, in order to smooth the downward trend in the domestic credit expansion. The general 
provision rate applied to consumer loans, that the financing companies granted, was decreased from $4 \%$ to $1 \%$, and, the rate was reduced from $8 \%$ to $2 \%$ for the consumer loans $30-90$ days overdue. On the contrary, the BRSA kept the above-mentioned provision rates at $4 \%$ and $8 \%$, respectively, for the financing companies that major part of the loans they granted was classified as non-performing loans or receivables having the nature of loss (BRSA, 2016). The regulation, issued in 2015, equalized the general provision rates applied to the banks and the financing companies.

\subsubsection{Limiting profit distribution}

Authorities can impose restrictions on profit distribution of the financial institutions in order to prevent the depletion of capital, and, keep the capital adequacy ratios above a minimum level. This type of restriction, usually, results in adding the retained profits to the capital. Thanks to the strengthened capital structure the banks can tackle the recession periods without extra capital injection.

The BRSA made the distribution of the banks' profits, on the financial operations conducted in 2009 or before, subject to preliminary permission in December 2009. This restriction came into effect in 2010, and, is still binding as of end-2015.

In order to comply with Basel III consensus the banks in Turkey are obliged to retain additional common equity capital according to an arrangement made by the BRSA. This new rule will, gradually, be introduced to the banks from 2016 on, and, it will indirectly restrict profit distribution. When the coverage rate of the actual additional common equity capital calculated by the bank relative to the additional common equity capital requirement goes below $100 \%$, the maximum profit distribution rate can be restricted within the $0 \%-60 \%$ range. There is a negative relationship between the additional capital requirement and the maximum profit to be distributed. In other words, the banks are allowed to distribute a higher portion of their profits, as the need for additional capital decreases (CBRT, 2013b; BRSA, 2014).

\subsubsection{Limiting leverage ratio}

Another important component of Basel III consensus reached following the Global Financial Crisis is restricting the leverage ratio of the financial institutions. The aim of this restriction is to keep the borrowing activities of the banks under control, and, therefore, the risks that they may be exposed due to excessive borrowing. According to Basel III consensus, leverage 
ratio is obtained by dividing the Tier 1 capital by the total risk amount. The total risk amount is roughly the sum of the risk associated with on-balance sheet assets, off-balance sheet transactions and financial derivative instruments. A low leverage ratio has the potential to pose severe risks for the financial system. The leverage ratio under Basel III was reported by the banks from 2013 on, and, being tested at least at 3\% since then. Given that $6 \%$ rate applied for the Tier 1 capital as a minimum, the lower limit to the leverage ratio can reduce the risks to which banks are exposed (BIS, 2011; CBRT, 2014).

The BRSA issued the communique on the leverage ratio restriction in 2013. With this regulation, the banks in Turkey were required to maintain the leverage ratio at least at $3 \%$ from 2015 onwards (BRSA, 2014).

\subsubsection{Capital conservation buffer and cyclical capital buffer}

The BCBS introduced two new capital buffers for protecting the equity of the banks against the developments in macroeconomic indicators, and, the credit cycles with Basel III consensus. These are called the capital conservation buffer and the cyclical capital buffer. The capital conservation buffer is the additional common equity capital that the banks must keep against the risk of aggravation in economic and financial indicators. Basel III envisaged that the capital conservation buffer would be put into effect gradually in 2016, and, fully implemented at a rate of $2.5 \%$ of the total risk-weighted assets in 2019 . The cyclical capital buffer is the additional common equity capital the banks should set aside in case the credit growth reaches a level which can increase the overall risk level of the financial sector. This capital buffer, which would be set within $0 \%-2.5 \%$ range based on the country's credit-to-GDP gap, came into effect worldwide in 2016 as well. The banking authority of a BIS member country should announce the amendments that lead to an increase in the cyclical capital buffer, twelve months prior to the implementation date. On the contrary, the regulations that reduce the cyclical buffer will go into effect immediately. The buffer ratios specified above are not compulsory minimum rates that the banks should maintain. However, the banking authority can impose restrictions on the profit distribution of the banks, when these conditions are not met (BIS, 2010; BIS, 2011; BOE, 2011; CBRT, 2014).

The BRSA settled the rules concerning the capital buffers with a communique, and, officially defined the capital conservation buffer and the bank-specific cyclical equity buffer, in 2013. The regulation set out that the additional common equity capital of a bank is the exceeding 
amount over the available common equity capital. Additional common equity capital requirement can be obtained by multiplying the sum of the capital conservation buffer and the bank-specific cyclical capital buffer with the risk weighted assets. The capital conservation buffer, which entered, gradually, into force in Turkey in 2016 in compliance with Basel III, would be fully applied at $2.5 \%$ from 2019 onwards. On the other hand, the BRSA holds the power to set the cyclical capital buffer between $0 \%$ and $2.5 \%$ for the risks of the banks in Turkey (CBRT, 2013b; BRSA, 2014).

\section{Assessment on the Macro-prudential Measures in Turkey}

\subsection{Overall Assessment}

Macro-prudential policy instruments used in Turkey between 2010 and 2015 are exhibited in the table below. Within the period under consideration, Turkey utilized all of the tools, except the limit on foreign currency lending, the limit on net open foreign currency position, the limit on currency mismatches. The authorities issued a number of credit-related macro-prudential instruments for managing the credit growth. However, those regulations were mainly related to individual loans. We did not notice any major regulation concerning the corporate loans granted to the companies during the period 2010-2015. Out of the capital-related measures, Turkey's authorities employed almost all of the tools on the list. The newly introduced capital buffers, i.e. the capital conservation buffer and the cyclical capital buffer, are envisaged to enter into force in 2016. As regards the liquidity-related measures, the emphasis was on the maturity mismatches and the reserve requirements. At this point we should note that the CBRT used the reserve requirements and the ROM as complementary tools to its monetary policy instruments such as interest rate corridor. Although there is no regulation in Turkey regarding the NSFR yet, we expect that the related regulations will come into force in 2018. By and large, macro-prudential measures in Turkey were used extensively since 2010, and, so far the new Basel III criteria were adapted in Turkey to a large extent (Table 5). 
Table 5

Macro-prudential policy tools used in Turkey, 2010-2015

\begin{tabular}{|c|c|c|}
\hline $\begin{array}{l}\text { Broad classification } \\
\text { of tools }\end{array}$ & Macro-prudential policy tools & $\begin{array}{c}\text { Measures came } \\
\text { into effect }\end{array}$ \\
\hline \multirow{4}{*}{ - Credit-related } & - Limiting credit expansion & $\begin{array}{c}2010,2011 \\
2013-2015\end{array}$ \\
\hline & - Changing Loan-to-Value ratio & 2011,2014 \\
\hline & - Changing Debt-to-Income ratio & 2013 \\
\hline & - Limiting foreign currency lending & $\mathrm{X}$ \\
\hline \multirow{9}{*}{$\circ$ Liquidity-related } & $\circ$ Limiting net open foreign currency position & $\mathrm{X}$ \\
\hline & $\circ$ Limiting currency mismatches & $\mathrm{X}$ \\
\hline & $\circ$ Limiting maturity mismatches & $2011,2013,2015$ \\
\hline & $\circ$ Changing reserve requirements & $2010-2015$ \\
\hline & $\begin{array}{l}\text { Non-traditional macro-prudential instruments } \\
\text { related to reserve requirements }\end{array}$ & \\
\hline & - The ROM & 2011-2015 \\
\hline & - Leverage based reserve requirements & 2014-2015 \\
\hline & $\circ$ Liquidity coverage ratio & 2015 \\
\hline & $\circ$ Net stable funding ratio & $\mathrm{X}$ \\
\hline \multirow{5}{*}{ - Capital-related } & - Countercyclical capital requirements & $2011-2015$ \\
\hline & - Changing loan-loss provisions & $\begin{array}{l}2010-2011, \\
2013,2015\end{array}$ \\
\hline & - Limiting profit distribution & 2010 \\
\hline & - Limiting leverage ratio & 2015 \\
\hline & $\begin{array}{l}\text { - Capital conservation buffer } \\
\text { - Cyclical capital buffer }\end{array}$ & $\alpha$ \\
\hline
\end{tabular}

Note. $\alpha$ : These tools are put into practice in 2016. Source: Lim et al. (2011), BIS (2011), BRSA, CBRT.

During the period under consideration, the authorities put 93 regulations into practice in total. According to the table below 2013, 2011 and 2015 were the years in which the regulations were issued most extensively. The number of the regulations, and, the trend of the figures indicate that Turkey followed a very active policy to maintain the financial stability. Among the measures, the authorities resorted to the reserve requirements, and, the reserve requirement-related tools including the ROM and the leverage based reserve requirement most frequently. 43 out of a total of 93 regulations employed between 2010 and 2015 were classified under the reserve requirements. The other frequently used instruments during the same period were related to the maturity mismatches and the credit expansion, respectively. Thus, we suggest that the authorities in Turkey gave the priority to the developments in the credit expansion, the availability of liquidity, alleviating the maturity mismatches between assets and liabilities to maintain financial stability. It is important to note that the authorities also aimed, indirectly, at stabilizing the exchange rate for a more foreseeable financial environment (Table 6). 
Table 6

Breakdown of Macro-Prudential Policy Tools Used in Turkey by Years, 2010-2015

\begin{tabular}{lccccccc}
\hline Macro-prudential tool & $\mathbf{2 0 1 0}$ & $\mathbf{2 0 1 1}$ & $\mathbf{2 0 1 2}$ & $\mathbf{2 0 1 3}$ & $\mathbf{2 0 1 4}$ & $\mathbf{2 0 1 5}$ & Total \\
\hline Limiting credit expansion & 1 & 1 & - & 2 & 4 & 2 & $\mathbf{1 0}$ \\
Changing Loan-to-Value ratio & - & 1 & - & - & 2 & - & $\mathbf{3}$ \\
Changing Debt-to-Income ratio & - & - & - & 2 & - & - & $\mathbf{2}$ \\
Limiting foreign currency lending & - & - & - & - & - & - & - \\
Limiting net open foreign currency position & - & - & - & - & - & - & - \\
Limiting currency mismatches & - & - & - & - & - & - & - \\
Limiting maturity mismatches & - & 6 & - & 8 & - & 4 & $\mathbf{1 8}$ \\
Changing reserve requirements & 6 & 8 & 11 & 6 & 4 & 8 & $\mathbf{4 3}$ \\
Liquidity Coverage Ratio & - & - & - & - & - & 1 & $\mathbf{1}$ \\
Net Stable Funding Rate & - & - & - & - & - & - & - \\
Countercyclical capital requirements & - & 1 & 1 & 2 & 1 & 1 & $\mathbf{6}$ \\
Changing loan-loss provisions & 1 & 2 & - & 4 & - & 1 & $\mathbf{8}$ \\
Limiting profit distribution & 1 & - & - & - & - & - & $\mathbf{1}$ \\
Limiting leverage ratio & - & - & - & - & - & 1 & $\mathbf{1}$ \\
Capital buffers & ${ }^{\alpha}$ & - & - & - & - & - & - \\
Total & $\mathbf{9}$ & $\mathbf{1 9}$ & $\mathbf{1 2}$ & $\mathbf{2 4}$ & $\mathbf{1 1}$ & $\mathbf{1 8}$ & $\mathbf{9 3}$ \\
\hline
\end{tabular}

Note. $\alpha$ : These tools are put into practice in 2016. Source: Lim et al. (2011), BIS (2011), BRSA, CBRT.

Concerning the institutional aspect of the macro-prudential policies, the CBRT and the BRSA made the massive part of the regulations between 2010 and 2015. The CBRT implemented a total of 60 arrangements while the BRSA issued 29 regulations during this period. This is because; these two authorities hold the power of moderating the amount of liquidity, the credit growth, and, the capital structure of financial institutions. The arrangements related to reserve requirements constitute the majority of the measures that the CBRT took during the period 20102015. The number of the regulations made by the CBRT goes down to 17 when we discard the reserve requirement-related regulations. Therefore, we infer that the BRSA plays a more active role than the CBRT in terms of using the macro-prudential tools. On the other hand, the SDIF and the Council of Ministers issued 4 regulations, in total, between 2010 and 2015 (Figure 1). 


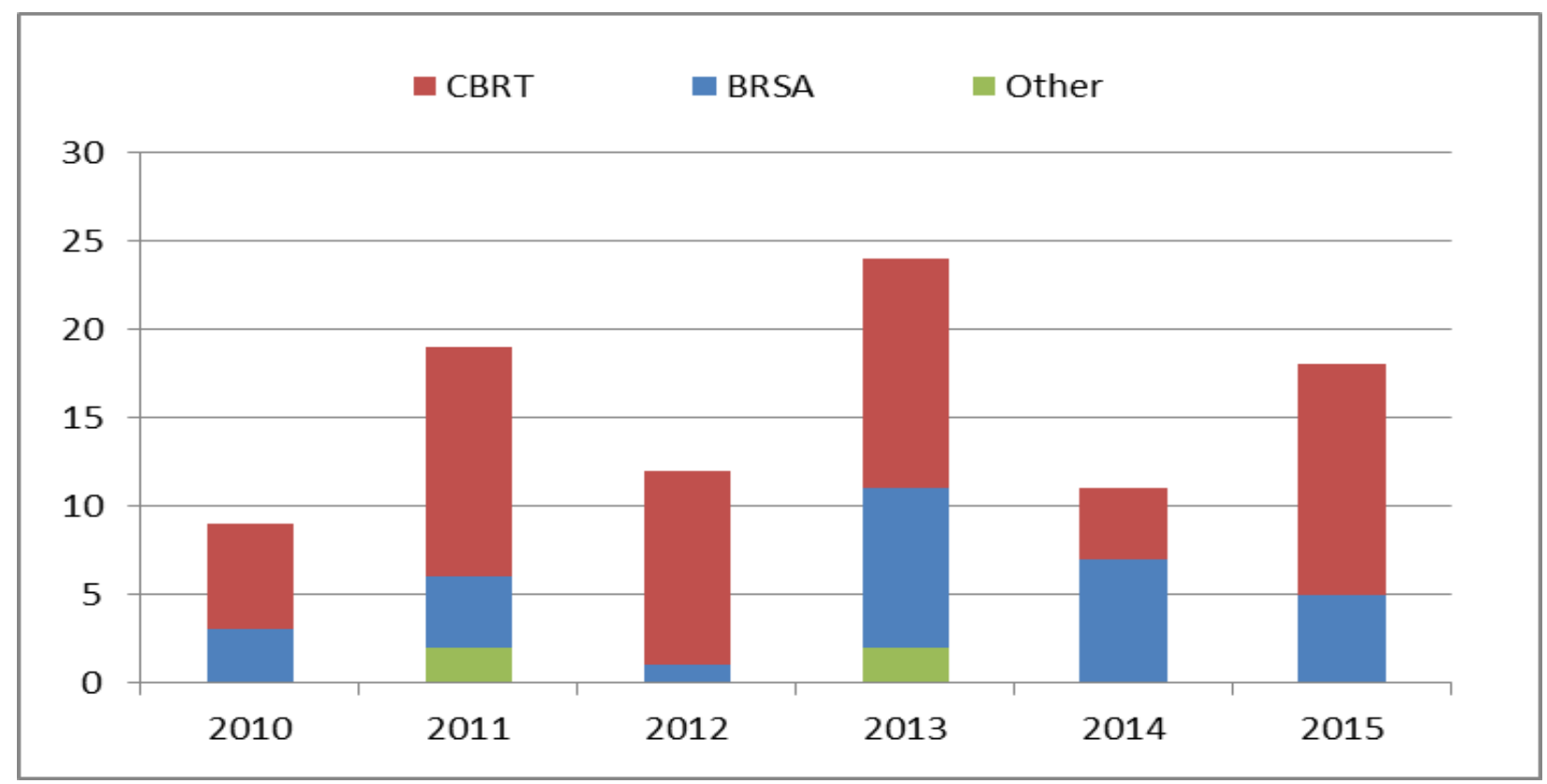

Figure 1. Breakdown of macro-prudential policy tools used in Turkey by institutions Adopted by BRSA, CBRT.

\subsection{Effectiveness}

It is worth noting that, in the previous sections, we explained a total of 14 macro-prudential instruments. Unfortunately there is no single measure that combines all of those instruments. Hence, we believe that it can be informative to present a few figures and mention the empirical studies on the effectiveness of the particular prudential tools used during the period 2010-2015. In this section we briefly discuss the effectiveness of the credit-related tools, the measures regarding the maturity mismatches, and, the ROM.

Having plummeted during the Global Financial Crisis, the real consumer credit growth began to recover in the fourth quarter of 2009. Then, following a rapid and continuous increase the growth rate rose up to $30.6 \%$ in 2011Q1. As we explained previously, the growth rates in domestic credit market alarmed the authorities to take countercyclical measures. Accordingly, the policy-making authorities put a number of credit-related tools into effect in 2010 and 2011. Figure 2 displays that personal loans fell sharply from 2011Q4 on. Thus one can argue that the measures against the credit growth may have actually worked. Yet, it is difficult to judge whether the fall in the credit expansion was solely a result of the macro-prudential measures or not. Because the problems related to the financial system and public finance in European economies in 2011 may 
have contributed to the slowdown of the capital supply from Europe, and, that in turn may have adversely affected the credit supply of the banks operating in Turkey (Figure 2).

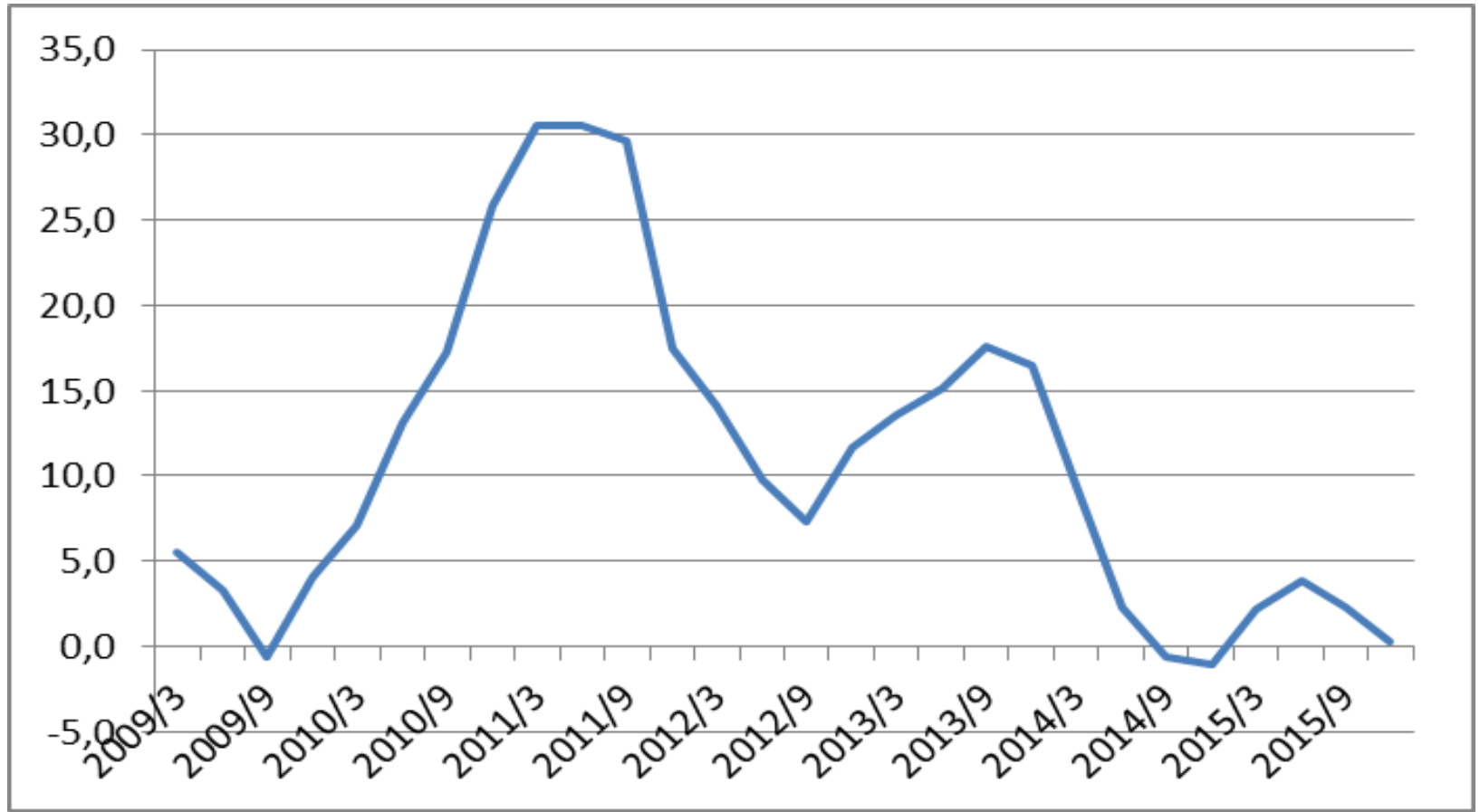

Figure 2. Annualized real growth rate of personal loans in Turkey, 2009-2015 (per cent). Adopted by BRSA, TURKSTAT.

An empirical study was published recently regarding the LTV arrangements in Turkey. Arslan, Kabaş \& Taşkın (2015) investigated whether the BRSA's LTV arrangements on vehicle loans affected the demand for the cars with a value exceeding TRL 50,000, or not. They estimated the effect of the LTV measure by using monthly data before, and, after the arrangement. Their results suggested that the arrangement led to a fall in the demand for more expensive cars immediately after it was put into effect in 2014. However, when the authors tested their model for various periods, the results showed that the effect of the LTV arrangement petered out in one year.

As regards the effectiveness of the measures to remedy the maturity mismatches in the financial system, we present the developments in the average maturity of the time deposits in TRL and foreign currencies in Turkey between 2010 and 2015 in the figure below. Throughout the period, the average maturity of both TRL and foreign currency deposits displayed similar trends. While the average maturity of the local currency deposits was at 47 days, which was quite short, in 2010Q1, it climbed over 60 days in 2011Q2 following the reserve requirement regulations made by the CBRT. Having remained over 60 days until the second half of 2013 this indicator tended to decrease from this period on. The average maturity of the foreign currency deposits also rose, 
gradually, up to 93 days in the early 2010s, and, started to go down from 2013Q3 on. Thus, in our opinion the Resolutions of Council of Ministers, especially the one regarding the withholding tax, issued in 2013 did not return the expected effects on time deposits (Figure 3).

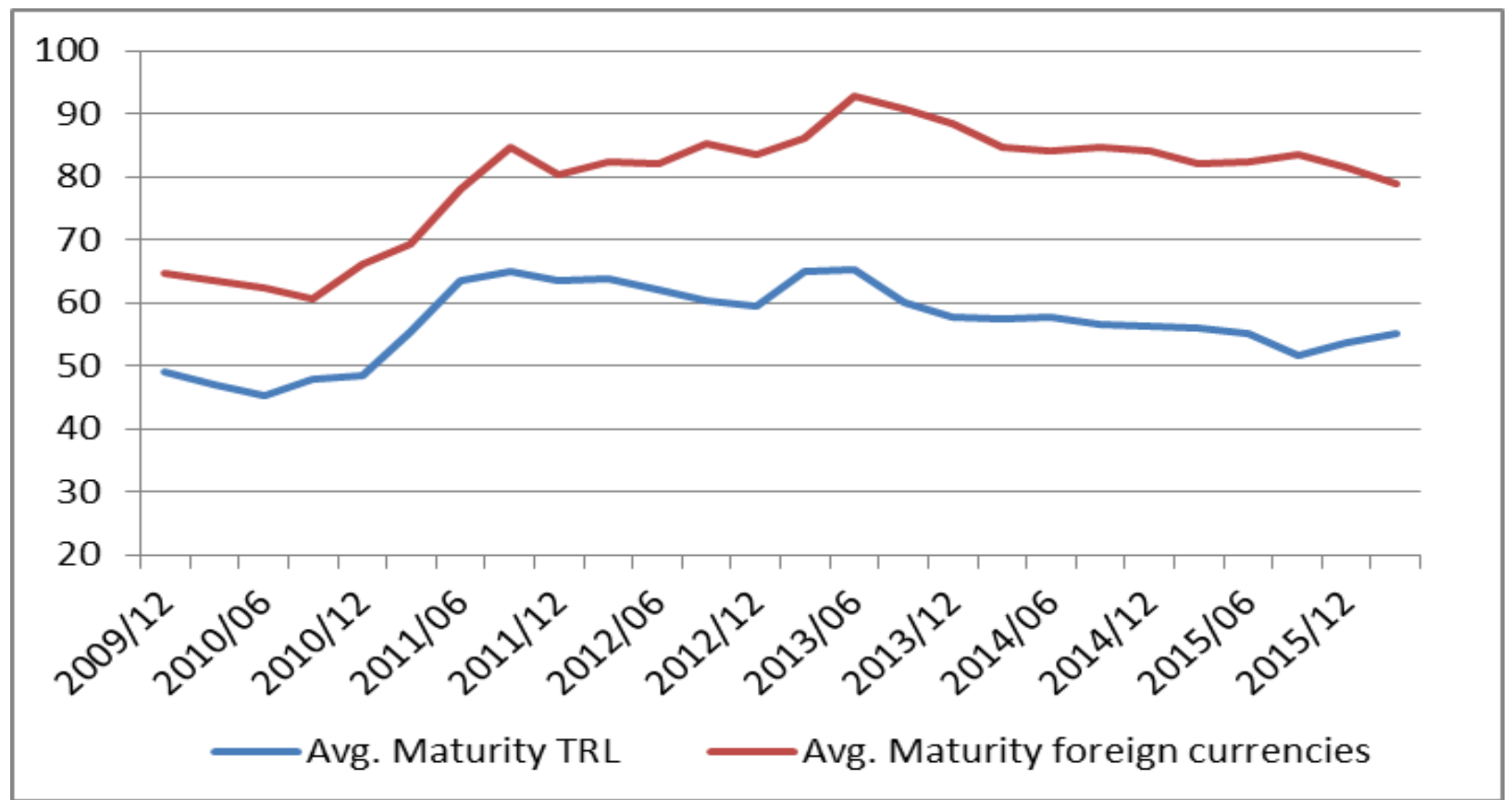

Figure 3. Average maturity of time deposits in Turkey, 2010-2015 (number of days). Own calculations based on BRSA data

Among the macro-prudential instruments used between 2010 and 2015, the ROM was a popular topic for doing empirical research. Oduncu, Akçelik \& Ermişoğlu (2013) analyzed the relationship between the ROM and the volatility of the exchange rate with a GARCH model for the period 2010:10-2012:10. The results of the study revealed that the ROM indeed contributed to a decrease in the volatility of the exchange rate. In another research paper Değerli \& Fendoğlu (2013) investigated the effects of the ROM on the expectations on the exchange rate, and compared the results with 10 emerging market economies. They showed that the likelihood of depreciation, and, large movements of Turkish Lira decreased after the ROM came into effect. However, the researchers commented on the results with caveat, and, stated that the sample period was a period of abundant global financial flows. Furthermore, in assessing the effectiveness of the ROM, one should carefully note that the ROM was not yet tested empirically against sudden stops, or, periods of capital flight. 


\section{Concluding Remarks}

The 2008-2009 Global Financial Crisis, adversely affected Turkey's economy and, the economy administration had to acknowledge that, in addition to the price stability, monitoring the financial stability is also crucial since 2010. The authorities in Turkey put numerous macroprudential arrangements into effect, and, adapted Basel III standards as fast as possible in order to bolster the financial stability. In addition to the widely used instruments such as the LTV and the DTI ratios, Turkey introduced two novel tools called the ROM and the leverage-based reserve requirement. In designing tailor-made policy tools when it needed, Turkey proved its institutional capacity and human capital potential. However, the extent to which the macro-prudential policies implemented in Turkey between 2010 and 2015 have been successful, is still a matter of controversy.

Considering that financial stability is a dynamic target, macro-prudential policies implemented in a country are also required to be continuously monitored and adjusted according to the developments in the economy. This points out the need for a strong coordination among the authorities that use and design the macro-prudential tools. In this respect, the main policy-making institutions regarding the macro-prudential policy measures in Turkey between 2010 and 2015, namely the CBRT and the BRSA, should put more emphasis on improving the collaboration with each other. In addition, it is necessary to keep working on alternative policy instruments that can be used against developments in the financial system.

Since macro-prudential policies constitute a relatively new research avenue, there is ample room for further investigation. Future studies can conduct empirical analyses to examine the overall impact of the macro-prudential regulations in Turkey. Furthermore, institutional arrangements regarding the execution of macro-prudential policies may be analyzed with references to the institutional models in other developing countries. Scholars can conduct comparative analysis between the policies pursued for maintaining the financial stability in Turkey and in other developing countries. 


\section{References}

Alper, K., Kara, H., \& Yörükoğlu, M. (2012). Reserve Options Mechanism. Central Bank of Turkey Research Notes in Economics, No: 12/28. Retrieved from http://tcmb.gov.tr/wps/wcm/connect/2b1d1e59-28b4-4025-95044e9bfee917d3/EN1228eng.pdf?MOD=AJPERES\&CACHEID=ROOTWORKSPACE2b1d 1e59-28b4-4025-9504-4e9bfee917d3.

Arslan, Y., Kabaş, G., \& Taşkın, A. A. (2015). Quantifying the Effects of Loan-to-Value Restrictions: Evidence from Turkey. Central Bank of Turkey Research Notes in Economics, No: 15/35. Retrieved from http://tcmb.gov.tr/wps/wcm/connect/4e8bb5c2ade3-4036-aff4-4ab154b0bc5/wp1535.pdf?MOD=AJPERES\&CACHEID=ROOT WORKSPACE4e8bb5c2-ade3-4036-aff4-c4ab154b0bc5.

Bank of England (2011). Instruments of Macroprudential Policy. Discussion Paper. Retrieved from http://www.bankofengland.co.uk/publications/Documents/other/ financialstability/discussionpaper111220.pdf.

Banking Regulation and Supervision Agency (BRSA) (2012). Annual Report 2011, Ankara. Banking Regulation and Supervision Agency (BRSA) (2014). Annual Report 2013, Ankara. Banking Regulation and Supervision Agency (BRSA) (2015). Annual Report 2014, Ankara. Banking Regulation and Supervision Agency (BRSA) (2016). Annual Report 2015, Ankara. Bank of International Settlements (BIS) (2010). Guidance for National Authorities Operating the Countercyclical Capital Buffer. Retrieved from http://www.bis.org/publ/bcbs187.pdf.

Bank of International Settlements (BIS) (2011). Basel III: A Global Regulatory Framework for More Resilient Banks and Banking Systems. Retrieved from http://www.bis.org/publ/bcbs189.pdf.

Bank of International Settlements (BIS) (2014). Basel III: The Net Stable Funding Ratio. Retrieved from http://www.bis.org/bcbs/publ/d295.pdf.

Başç1, E., \& Kara, H. (2011). Financial Stability and Monetary Policy. Central Bank of Turkey Working Papers, No: 11/08. Netrieved http://tcmb.gov.tr/wps/wcm/connect/5c35acf8-f99f-442a-b40909245381cbf4/WP1108E.pdf?MOD=AJPERES\&CACHEID=ROOTWORKSPACE5c35a cf8-f99f-442a-b409-09245381cbf4. 
Binici, M., \& Köksal, B. (2012). Credit Booms in Turkey [Turkish]. Central Bank of Turkey Research Notes in Economics, No: 12/15. Retrieved from http://tcmb.gov.tr/wps/wcm/connect/4352a031-fb98-46fa-ae4d-2331e5dfac6c /EN1215eng.pdf?MOD=AJPERES\&CACHEID=ROOTWORKSPACE4352a031-fb9846fa-ae4d-2331e5dfac6c.

Blanchard, O., Dell'Ariccia, G., \& Mauro, P. (2010). Rethinking Macroeconomic Policy. Journal of Money, Credit, and Banking, 42 (Supplement), 199-215. Retrieved from Econpapers.

Caruana, J. (2010). Macroprudential Policy: Working towards a New Consensus. Remarks at the High-Level Meeting on "The Emerging Framework for Financial Regulation and Monetary Policy" jointly organised by the BIS's Financial Stability Institute and the IMF Institute, Washington DC. Retrieved from http://www.bis.org/speeches/sp100426.pdf.

Central Bank of the Republic of Turkey (CBRT) (2010). Monetary Policy Exit Strategy, Ankara.

Central Bank of the Republic of Turkey (CBRT) (2011a). Financial Stability Report, No. 12 (May), Ankara.

Central Bank of the Republic of Turkey (CBRT) (2011b). Financial Stability Report, No. 13 (November), Ankara.

Central Bank of the Republic of Turkey (CBRT) (2013a). Financial Stability Report, No. 16 (May), Ankara.

Central Bank of the Republic of Turkey (CBRT) (2013b). Financial Stability Report, No. 17 (November), Ankara.

Central Bank of the Republic of Turkey (CBRT) (2014a). Financial Stability Report, No. 18 (May), Ankara.

Central Bank of the Republic of Turkey (CBRT) (2014b). Financial Stability Report, No. 19 (November), Ankara, 2014b.

Central Bank of the Republic of Turkey (CBRT) (2015). Financial Stability Report, No. 21 (November), Ankara.

Central Bank of the Republic of Turkey (CBRT) (2016). Annual Report 2015, Ankara.

Clement, P. (2010). The Term Macroprudential: Origins and Evolution. BIS Quarterly Review. Retrieved from http://www.bis.org/publ/qtrpdf/r_qt1003h.pdf.

Değerli, A., \& Fendoğlu, S. (2013). Reserve Option Mechanism as a Stabilizing Policy Tool: Evidence from Exchange Rate Expectations. Central Bank of Turkey Research Notes in 
Economics, No: 13/28. Retrieved from http://tcmb.gov.tr/wps/wcm/connect/1532a3b217f5-41a9-957f-

a33d368b4d60/WP1328.pdf?MOD=AJPERES\&CACHEID=ROOTWORKSPACE1532a3 b2-17f5-41a9-957f-a33d368b4d60.

Galati, G., \& Moessner, R. (2011). Macroprudential Policy - A Literature Review. BIS Working Papers, No. 337. Retrieved from http://www.bis.org/publ/work337.pdf.

Hannoun, H. (2010). Towards a Global Financial Stability Framework. Speech at the 45th SEACEN Governors' Conference, Siem Reap province, Cambodia. Retrieved from http://www.bis.org/speeches/sp100303.pdf.

Hellwig, M. (2014). Systemic-risk and Macro-prudential Policy. In A. Houben, R. Nijskens \& M. Teunissen (Eds.), Putting Macroprudential Policy to Work (pp. 42-77). Amsterdam: De Nederlandsche Bank.

Lim, C., Columba, F., Costa, A., Kongsamut, P., Otani, A., Saiyid, M., ... Wu, X. (2011). Macroprudential Policy: What Instruments and How to Use Them: Lessons from Country Experiences. International Monetary Fund Working Papers, (WP/11/238). Retrieved from http://www.imf.org/external/pubs/ft/wp/2011/wp11238.pdf.

Oduncu, A., Akçelik, Y., Ermişoğlu, E. (2013). Reserve Options Mechanism and FX Volatility. Central Bank of Turkey Research Notes in Economics, No: 13/03. Retrieved from http://tcmb.gov.tr/wps/wcm/connect/ee7ed06a-4fe9-4fef-9120-

5dee2fd0e273/WP1303.pdf?MOD=AJPERES\&CACHEID=ROOTWORKSPACEee7ed06 a-4fe9-4fef-9120-5dee2fd0e273.

Özatay, F. (2013). Monetary economics: Theory and policy [Turkish]. Ankara: Efil.

Central Bank of the Republic of Turkey (CBRT) (2009). Monetary and Exchange Rate Policy Report 2010, Ankara.

Vural, U. (2013). Rise of the Non-traditional Monetary Policies [Turkish]. Unpublished proficiency dissertation submitted to the Central Bank of the Republic of Turkey. Retrieved from http://tcmb.gov.tr/wps/wcm/connect/b5c5e45f-7cf1-47e2-966d4b4e6d7d60a7/umutvural.pdf?MOD=AJPERES\&CACHEID=ROOTWORKSPACEb5c5e 45f-7cf1-47e2-966d-4b4e6d7d60a7. 